\title{
Energy dependency and sustainable regional development in the Baltic States - a review
}

\author{
Dalia Štreimikien $\dot{\mathrm{A}}^{\mathrm{A}^{*}, \text { Wadim Strielkowski }}{ }^{\mathrm{B}}$, Yuriy Bilan' ${ }^{\mathrm{C}}$, Ignas Mikalauskas ${ }^{\mathrm{D}}$ \\ Received: February 24, 2016 | Revised: May 9, 2016 | Accepted: June 2, 2016 \\ DOI: 10.18421/GP20.02-04
}

\begin{abstract}
Energy security is one of the most important indicators of sustainable regional development and "green" growth in implementation of EU strategy Europe 2020. It can provide the harmonized development and cohesion of "old" and "new" EU member states. Our paper conducts a comparative study of energy dependency and energy security indicators in the Baltic States. The Baltic countries achieved enormous progress in the use of renewable energy sources and energy efficiency since their $\mathrm{EU}$ accession in 2004. The increase of renewable energy capacities in Baltic States also contributed to the reduction of energy intensity and carbon intensity of economy and energy import dependency. Our results show that amongst all three states, it was Estonia that had achieved the best results in increased use of renewables and energy efficiency improvements and had distinguished itself with the best indicators and economic and regional policy outcomes.
\end{abstract}

Keywords: sustainable energy, economic growth, regional development, energy security, Baltic States

\section{Introduction}

"Green growth" is resource-efficient, cleaner economic growth which is more resilient without slowing the pace of economic development. Green growth policies pursue a variety of goals and they are best served by a combination of instruments (Dresner, 2008; Bilan, 2013; Csigéné Nagypál, 2015; Kasperowicz, 2015). Green growth of the EU member states can provide cohesion and harmonious development of the EU as a whole (Cappelen, et al., 2003; Vasauskaite and Streimikiene, 2014). One of the main issues related to the green growth is development of sustainable energy. There are various methods and frameworks to assess sustainable energy development and its interrelations with green growth. Sustainable energy development covers such important dimensions of sustainability: energy security (economic), energy affordability (social) and environmental impact (environmental).
The International energy agency (IEA) defines energy security as "the uninterrupted availability of energy sources at an affordable price". Energy security has many dimensions: long-term energy security mainly deals with timely investments to supply energy in line with economic developments and sustainable environmental needs. Short-term energy security focuses on the ability of the energy system to react promptly to sudden changes within the supply-demand balance. Lack of energy security is thus linked to the negative economic and social impacts of either physical unavailability of energy, or prices that are not competitive or are overly volatile.

The aim of this paper is to review and compare achievements of Baltic States in reducing energy dependence by applying set of sustainable energy development indicators. We do so through comparative analysis, graphical analysis, systematization and gen-

\footnotetext{
A Faculty of Economics and Finance Management, Mykolas Romeris University, Ateities g. 11, Vilnius, LT-08303, Lithuania

B Cambridge Judge Business School, University of Cambridge, Trumpington Street, Cambridge, CB2 1AG, United Kingdom

C Faculty of Economics Science and Management, University of Szczecin, ul. Mickiewicza 64, 71-101, Szczecin, Poland

D Faculty of economics and finance management, Mykolas Romeris University, Ateities g. 11, Vilnius, LT-08303, Lithuania

* Corresponding author: Dalia Štreimikienè, e-mail: daliastreimikiene@mruni.eu
} 
eralization. The main tasks the authors set for themselves are the following:

- reviewing EU policy documents on energy dependence and energy security

- analysing and comparing achievements of Baltic States in energy security;

- developing policy recommendations.

\section{Energy dependence and energy security}

The EU imports more than half of all the energy it consumes. Its import dependency is particularly high for crude oil (more than 90\%) and natural gas (66\%). The total import bill is more than $€ 1$ billion per day. Many EU member states are also heavily reliant on a single supplier, including some that rely entirely on Russia for their natural gas. This dependence leaves them vulnerable to supply disruptions, whether caused by political or commercial disputes, or infrastructure failure. For instance, a 2009 gas dispute between Russia and transit-country Ukraine, left many EU countries with severe shortages. In response to these concerns, the European Commission released its Energy Security Strategy in May 2014. The Strategy aims to ensure a stable and abundant supply of energy for European citizens and the economy. The main measures to EU ensure secure supplies of energy were defined: the EU should follow a market-based approach to guarantee secure supplies. Interventionist measures by governments should be avoided; countries should increase energy coordination with each other, including through the maximisation of interconnector capacity and the removal of restrictions to cross-border energy trade; short-term behavioural changes should be enacted to boost energy efficiency and lower demand and the EU's Gas Coordination Group should continuously monitor developments in the gas supply.

The most important EU policy document - strategy Europe 2020 also emphasizes security of energy supply because energy is crucial for economic growth. Europe 2020 is the EU's growth strategy for the coming decade. In a changing world, EU seeks to become a smart, sustainable and inclusive economy. These three mutually reinforcing priorities should help the EU and the Member States deliver high levels of employment, productivity and social cohesion. Concretely, the Union has set five ambitious objectives - on employment, innovation, education, social inclusion and climate/energy - to be reached by 2020 . Each Member State has adopted its own national targets in each of these areas (Hallegatte, et al., 2011; Balitskiy, et al., 2014; Balitskiy, et al., 2016; Białowąs, 2015). Concrete actions at EU and national levels underpin the strategy. The 2015 European Semester kicked off in 2014 November with the Annual Growth Survey, which outlined the new Commission's three-pillar jobs and growth strategy: boosting investment, accelerating structural reforms and pursuing responsible, growth-friendly fiscal consolidation. In February 2015, the European Commission published a series of country reports analysing Member States' economic policies. In May 2015, the Commission published the country-specific recommendations for each Member State, along with an overarching Communication on how to strengthen and sustain the recovery, and how the streamlined European Semester is implemented. There several important indicators of green growth indicated European Commission Reports (see Jänicke, 2011; Reilly, 2012; Schmalensee, 2012).

Table 1 demonstrates that the green growth performance indicators consist from macroeconomic indicators, sectoral indicators, and security of energy supply (Heal, 2013; Clowes, Choroś-Mrozowska, 2015).

Table 1. Green growth indicators

\begin{tabular}{|c|c|}
\hline Green growth performance indicators & $\begin{array}{c}\text { Unit of } \\
\text { measurement }\end{array}$ \\
\hline \multicolumn{2}{|l|}{ Macroeconomic indicators } \\
\hline Energy intensity & kgoe/€ \\
\hline Carbon intensity & $\mathrm{kg} / €$ \\
\hline $\begin{array}{l}\text { Resource intensity (reciprocal of resource } \\
\text { productivity) }\end{array}$ & $\mathrm{kg} / €$ \\
\hline Waste intensity & $\mathrm{kg} / €$ \\
\hline Energy balance of trade & $\%$ GDP \\
\hline Energy weight in HICP & $\%$ \\
\hline $\begin{array}{l}\text { Difference between energy price change } \\
\text { and inflation }\end{array}$ & $\%$ \\
\hline $\begin{array}{l}\text { Ratio of environmental taxes to labour } \\
\text { taxes }\end{array}$ & Ratio \\
\hline Ratio of environmental taxes to total taxes & Ratio \\
\hline \multicolumn{2}{|l|}{ Sectoral indicators } \\
\hline Industry energy intensity & kgoe / € \\
\hline $\begin{array}{l}\text { Share of energy-intensive industries in the } \\
\text { economy }\end{array}$ & $\%$ GDP \\
\hline $\begin{array}{l}\text { Electricity prices for medium-sized } \\
\text { industrial users** }\end{array}$ & $€ / \mathrm{kWh}$ \\
\hline $\begin{array}{l}\text { Gas prices for medium-sized industrial } \\
\text { users*** }\end{array}$ & $€ / \mathrm{kWh}$ \\
\hline Public R\&D for energy & $\%$ GDP \\
\hline Public R\&D for the environment & $\%$ GDP \\
\hline Recycling rate of municipal waste & Ratio \\
\hline Share of GHG emissions covered by ETS* & $\%$ \\
\hline Transport energy intensity & kgoe / € \\
\hline Transport carbon intensity & $\mathrm{kg} / €$ \\
\hline \multicolumn{2}{|l|}{ Security of energy supply } \\
\hline Energy import dependency & $\%$ \\
\hline
\end{tabular}




\begin{tabular}{|l|c|}
\hline Diversification of oil import sources & $\mathrm{HHI}$ \\
\hline Diversification of energy mix & $\mathrm{HHI}$ \\
\hline Renewable energy share of energy mix & $\%$ \\
\hline
\end{tabular}

Source: Own results

All EU Member States committed to the Europe 2020 strategy. In addition to indicators of security of energy supply, there are other indicators addressing energy dependency issues. Three broad dimensions are identified as relevant: (1) security of supply, defined as the uninterrupted availability of energy sources at an affordable price; (2) energy and carbon intensity as their improvement contributes to reducing energy dependence while bringing additional economic and environmental benefits; (3) the contribution of energy products to trade given its potential impact on the current account deficit (European Commission, 2014).

However, each country has different economic circumstances and translates the overall $\mathrm{EU}$ objectives into national targets in its National Reform Programme - a document which presents the country's policies and measures to sustain growth and jobs and to reach the Europe 2020 targets. The National Reform Programme were presented by EU member states in parallel with its Stability/Convergence Pro- gramme, which sets out the country's budgetary plans for the coming three or four years All indicators presented in Table 1 were assessed by EU member States in their National Reform programmes.

\section{Energy dependency and security in Baltic States}

Reduction of energy dependency and increase in energy security are the priorities of EU cohesion policy and can also ensure harmonious development of EU member states. The European Commission encourages more intensive use of the Structural and Cohesion funds EU Structural Funds for ensuring reduction of energy dependency and ensuring green growth. Achievements of Baltic States in reduction of energy dependency in 2012 are summarized in are summarized in Table 2.

According to the macroeconomic indicators related to energy intensity and carbon intensity, Latvia and Lithuania are the best-performing countries. However, according to the industry energy intensity, Latvia is the worst performing country also having the highest energy intensity of its industry. The detail analysis and development of energy and carbon intensity indicators in Baltic States are provided in Table 3.

Table 2. Achievements in reduction of energy dependency by Baltic States in 2013

\begin{tabular}{|c|c|c|c|c|c|}
\hline Green growth performance indicators & Unit of measurement & Lithuania & Latvia & Estonia & EU-28 \\
\hline \multicolumn{6}{|l|}{ Energy and carbon intensity of economy } \\
\hline Energy intensity & kgoe/€ & 0.29 & 0.33 & 0.48 & 0.15 \\
\hline Carbon intensity & $\mathrm{kg} / €$ & 0.89 & 0.79 & 1.50 & 0.6 \\
\hline Industry energy intensity & kgoe / € & 0.18 & 0.39 & 0.23 & 0.14 \\
\hline Transport energy intensity & kgoe / € & 0.57 & 0.95 & 0.96 & 0.73 \\
\hline Transport carbon intensity & $\mathrm{kg} / €$ & 1.63 & 2.53 & 2.76 & 1.9 \\
\hline Energy intensity of households & kgoe/€ & 0.106 & 0.167 & 0.156 & 0.044 \\
\hline Carbon intensity of households & $\mathrm{kg} / €$ & 0.11 & 0.20 & 0.19 & 0.19 \\
\hline Share of energy intensive sectors in total GVA & $\%$ & - & - & 12.6 & - \\
\hline Energy weight in HICP & $\%$ & 16.4 & 15.7 & 14.7 & 10.0 \\
\hline \multicolumn{6}{|c|}{ Contribution of energy products to trade to balance } \\
\hline Trade balance of total energy & $\%$ GDP & -7.6 & -6.0 & -1.4 & -2.9 \\
\hline Current account balance & $\%$ GDP & -2.7 & -1.1 & -0.4 & -0.7 \\
\hline Relative energy trade balance & $\%$ & -18.2 & -43.1 & -15.2 & -36.7 \\
\hline Share of energy in total trade & $\%$ & 27.3 & 11.5 & 11.2 & 12.1 \\
\hline Macro trade openness & $\%$ GDP & 147.4 & 103.8 & 140.7 & 94.2 \\
\hline \multicolumn{6}{|l|}{ Security of energy supply } \\
\hline Energy import dependency & $\%$ & 80.3 & 56.4 & 17.1 & 54 \\
\hline Diversification of oil import sources & $\mathrm{HHI}$ & 0.75 & 0.28 & 0.20 & 0.09 \\
\hline Diversification of energy mix & $\mathrm{HHI}$ & 0.29 & 0.30 & 0.45 & 0.24 \\
\hline Renewable energy share of energy mix & $\%$ & 16.4 & 36.4 & 14.1 & 9.0 \\
\hline
\end{tabular}

Source: European Commission (2015a, 2015b, 2015c) 


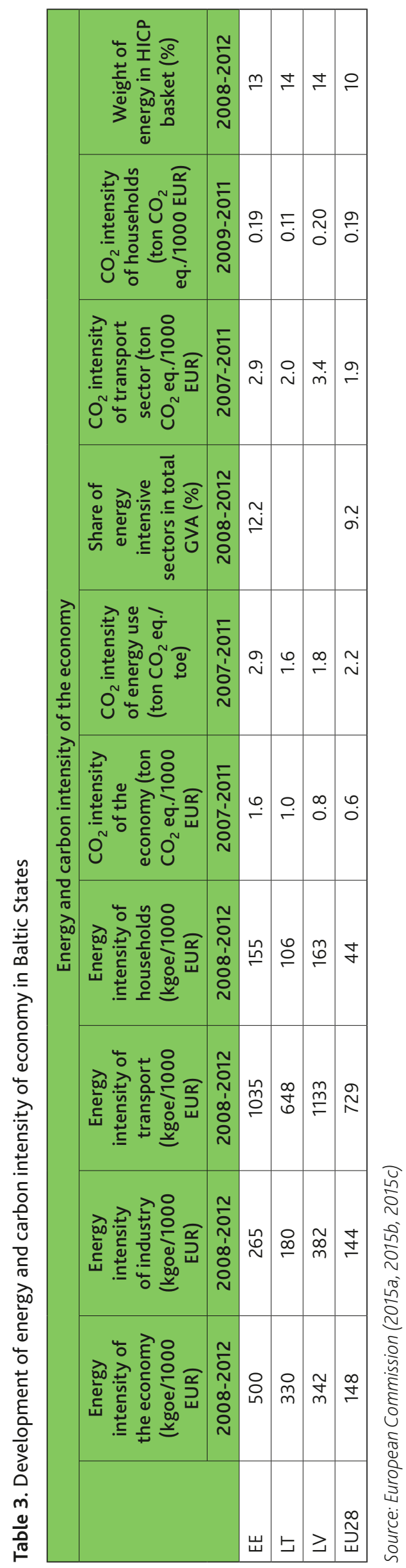

In some EU Member States, improvements in energy intensity were not equally distributed over time. All Baltic States have recorded a decline in gross energy intensity since 2004, but some countries, such as Latvia and Estonia concentrated most of their efforts to the beginning of the 200os (Ciegis, et al., 2014; Pazeraite, et al., 2014; Vasauskaite, Streimikiene, 2014; Urbaniec, 2015).

It becomes apparent that Lithuania has the lowest energy and carbon intensity as well as the lowest carbon intensity in all sectors among Baltic States therefore Lithuania is the best performing country in terms of energy and carbon intensity indicators which contribute to reducing energy dependence while bringing additional economic and environmental benefits. Estonia has the highest energy and carbon intensity.

Another way to assess the vulnerability of Member States to energy supply shock is to look at the importance of energy items in the consumers' basket (HICP). Given the variety of weights that energy has in the consumers' basket of Member States, a rise in energy prices would impact differently on the disposable income of households. The lowest weight of energy in HICP basket (\%) is in Estonia though it is significantly higher comparing with EU-28 average.

From Table 2 it appears that regarding security of energy supply Lithuania has the highest energy important dependency. The lowest energy import dependency is in Estonia because country has abundant local energy resources such as oil shale. In addition Lithuania has the highest oil import diversification rate and quite low diversification of energy mix. Moreover, Estonia can be distinguished from the other countries in question due to its high diversification of energy mix.

Table 4 summarizes and compares the dynamics of the main indicators of security of energy supply among Baltics States.

It becomes clear that all Baltic States (except for Estonia) have a very high important dependency rate (total, oil, solid fuels and natural gas). Though the vast majority of Member States display very high import dependence for petroleum products, while no country depends fully on a single supplier however Lithuania has the lowest degree of diversification of import sources among EU-28. Only Lithuania displays a share of petroleum products in the energy mix above the EU average while the other EU member states $s$ are significantly below. It should however be noted that considering only crude oil, the diversification of import sources is in Lithuanian case much more reduced and depend essentially on only one supplier, Russia. Also the vast majority of EU Member States count for their solid fuels supply solely on non-EEA countries. The countries that appear the most exposed 


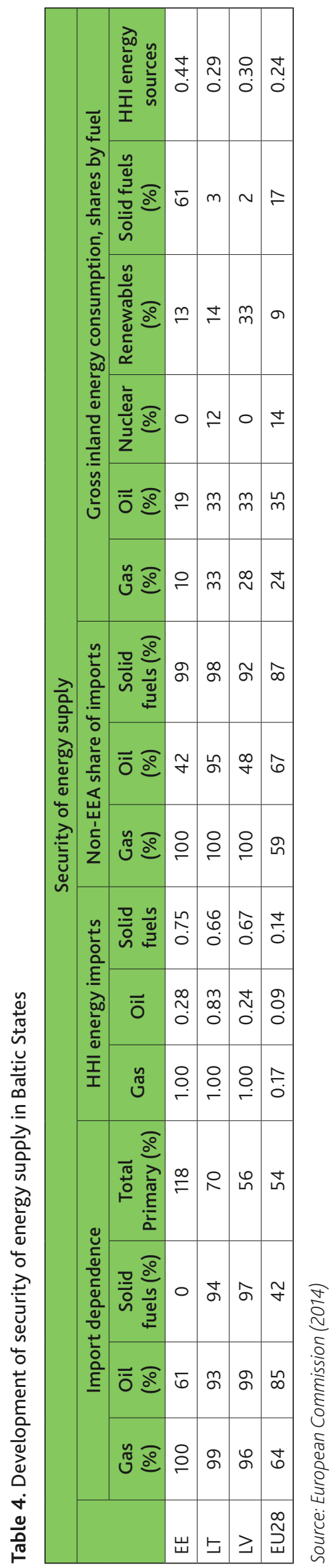

in this sense are Latvia and Lithuania. While Latvia imports $75 \%$ of its solid fuels from Russia but has increasing trade relations with the US, which share in imports went from o to $22 \%$ between 2009 and 2012. The import dependence for solid fuels has been diminishing over time in the vast majority of Member States, in particular in Estonia.

Another indicator of security of supply that can be assessed is the HHI for the energy mix, i.e. the degree of diversification of the composition of the energy mix of a Member State. All other things being equal, the more diversified a country's energy mix is, the less likely it is to suffer from the impact of a supply shock affecting one specific energy source. The HHI for the energy mix of the whole EU has been progressively decreasing, signalling a growing diversification of the mix.

Energy dependency indicators of Baltic States related to the trade dimension are compared in Table 5 that follows.

The analysis shows that all Baltic States have negative energy balance of trade. The (net) energy trade balance is expressed as a percentage of GDP. All other things being equal, the more negative this balance, the higher the likelihood that the current account is vulnerable to energy price shocks, and hence the bigger the contribution of trade in energy products to an external imbalance. The worst situation is in Lithuania.

Relative energy trade balance is also negative in all Baltic States it means that if all other things being equal, the more energy imports outstrip energy exports relative to total trade in energy, the larger the energy trade deficit becomes and hence the more vulnerable the country is to energy shocks related to trade. Latvia is the most vulnerable country among Baltic States in terms of relative energy trade balance.

Another indicator is the share of energy trade in total trade: all other things being equal, the larger the share of energy in a country's international trade, the larger the impact of the relative energy trade balance is on the net energy trade balance. Lithuania has the highest share of energy in total trade and is the most vulnerable in this sense.

The indicator of macro trade openness shows the relative size of a country's international trade vis-avis the size of its economy. Note that this indicator is not energy-related. It expresses the notion that higher macro trade openness amplifies the effects of the previous two factors. Lithuania has the highest macro trade openness among Baltic States. 
Table 5. Energy dependency indicators related to trade dimension in Baltic States

\begin{tabular}{|c|c|c|c|c|c|c|c|}
\hline \multicolumn{8}{|c|}{ Contribution of energy products to trade balance } \\
\hline & \multicolumn{3}{|c|}{$\begin{array}{l}\text { Trade balance of energy products } \\
\text { (\% of GDP) }\end{array}$} & \multirow{2}{*}{$\begin{array}{l}\text { Current } \\
\text { account } \\
\text { balance (\% } \\
\text { of GDP) }\end{array}$} & \multicolumn{3}{|c|}{ DECOMPOSITION (related to total energy trade) } \\
\hline & $\begin{array}{l}\text { Petroleum } \\
\text { products }\end{array}$ & Gas & Total & & $\begin{array}{l}\text { Relative energy } \\
\text { trade balance } \\
\text { (\%) }\end{array}$ & $\begin{array}{l}\text { Share of energy } \\
\text { in total trade } \\
\text { (\%) }\end{array}$ & $\begin{array}{c}\text { Macro trade } \\
\text { openness } \\
\text { (\% of GDP) }\end{array}$ \\
\hline & 2009-2013 & 2009-2013 & $2009-2013$ & 2008-2012 & 2013 & 2013 & 2013 \\
\hline $\mathrm{EE}$ & -1.5 & -1.2 & -1.6 & -0.4 & -15.2 & 11.2 & 140.7 \\
\hline LT & -3.4 & -2.8 & -6.8 & -2.7 & -18.2 & 27.3 & 147.4 \\
\hline LV & -3.2 & -2.1 & -5.2 & -1.1 & -43.1 & 11.5 & 103.8 \\
\hline EU28 & -1.9 & -0.8 & -2.9 & -07 & -36.7 & 12.1 & 94.2 \\
\hline
\end{tabular}

Source: European Commission (2014)

\section{Energy security indicators in Baltic States}

The most important indicators of energy dependency and energy security were selected from Table 2 and further used to compare Baltic States in accordance with their achievements in the field of energy security. Figure 1 depicts the development of the main indicators of energy dependency and security in Baltic States.

The most important indicator of green growth is energy intensity of GDP, as far as this indicator also represents competitiveness, environmental sustainability and energy security issues.

The reduction of energy intensity in member states has direct impact on environmental and pollution reduction, climate change mitigation and on increase of competitiveness of economy and security of energy supply. In Figure 1 the trends of energy intensity of GDP is compared in Baltic States. As one can see from Figure 1 though all Baltic States have energy intensity well above EU-28 level the highest energy intensity is in Estonia and the lowest one in Lithuania. Comparing data of year 2004 with energy intensity in 2012 one

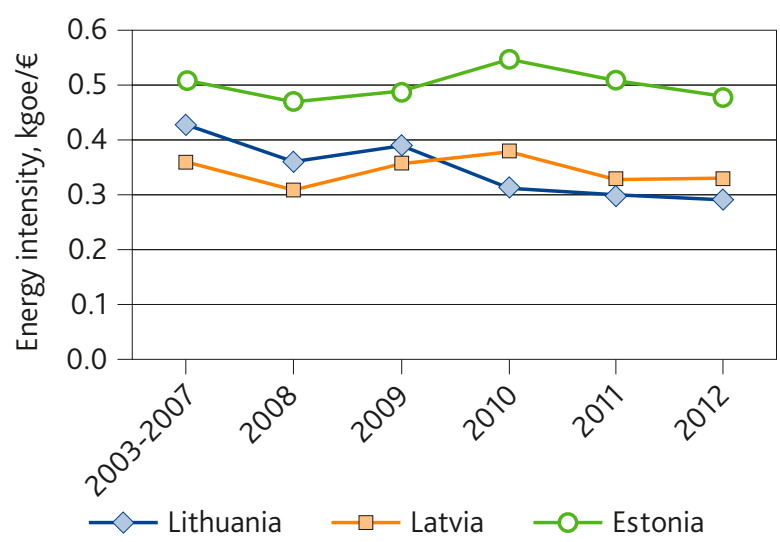

Figure 1. Energy intensity in Baltic States

Source: European Commission. 2016, Eurostat, Data, Database http://ec.europa.eu/eurostat/data/database can notice that energy intensity was decreasing since entering EU in all analysed countries however economic crisis had negative impact and energy intensity stared to increase however in Estonia energy intensity increase can be noticed since 2007 but in 2010 this trend has dramatically changed and energy intensity began to decrease. In other analysed countries the trend of energy intensity decrease can be noticed following the recovery from economic crisis in 2010.

The $\mathrm{CO}_{2}$ intensity of the economy for the whole EU decreased substantially since 2001 by about $23 \%$. It declined for all Member States. However, similarly to the energy intensity, a trend break occurred around 2008 for a group of countries when the carbon intensity of these economies started increasing. This is also the case for Estonia and Latvia.

Figure 3 demonstrates the persistently negative energy trade balance in all analysed countries. In 2013, the negative energy balance in trade in the EU amounted to $3.1 \%$ of EU GDP up from $2.1 \%$ of 2009 therefore the negative trends can be noticed in all analysed countries. Especially in Lithuania this trend is very negative since

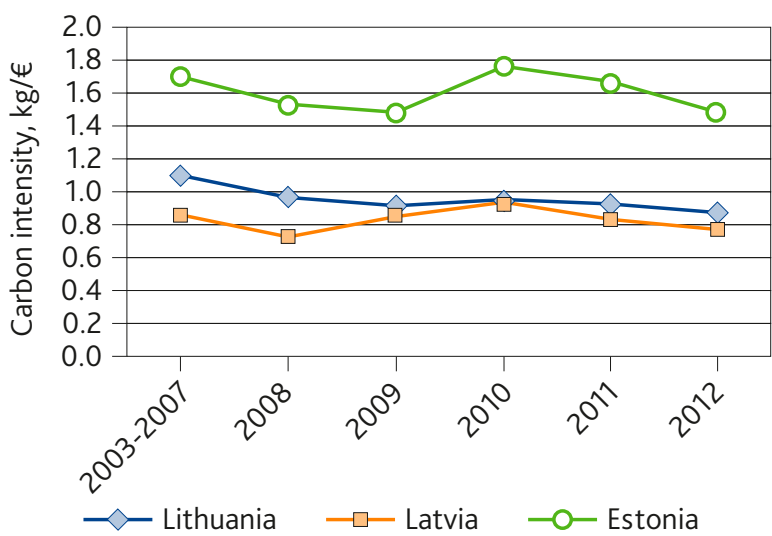

Figure 2. Carbon intensity in Baltic States

Source: European Commission. 2016. Eurostat, Energy Statistics Database http://ec.europa.eu/eurostat/data/database 


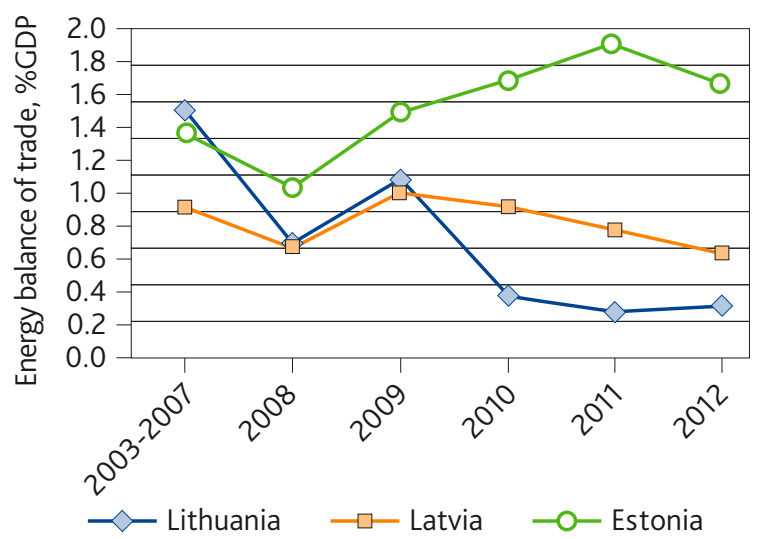

Figure 3. Energy balance of trade in Baltic States

Source: European Commission. 2016. Eurostat, Energy Statistics Database http://ec.europa.eu/eurostat/data/database

the closure of the second unit at Ignalina NPP in 2009. In 2003-2008 Ignalina NPP was generating about $80 \%$ of electricity produced in Lithuania.

Figure 4 demonstrates that the highest energy dependency rate in 2012 was recorded in Lithuania. This is related with the closure of Ignalina NPP in 2009 and increase of energy import. Before closure of Ignalina NPP Lithuania was net energy exporter. The lowest energy import dependency is in Estonia though it has slightly decreased in 2012 comparing with year 2011. Estonia has abundant oil shale resources and has been utilising these resources in energy sector quite intensively however with entrance in force of stringent $\mathrm{EU}$ environmental regulations the use of oil shale having high sulphur content is diminishing.

It becomes apparent that Latvia have high energy dependency rate well above EU-28 level however the trends in Latvia are very positive and energy dependency rates have decreased in these countries from almost $70 \%$ in 2004 to $55-60 \%$ in 2012 .

From Figure 5 one can see that Estonia has the highest diversification of energy and since 2009 the

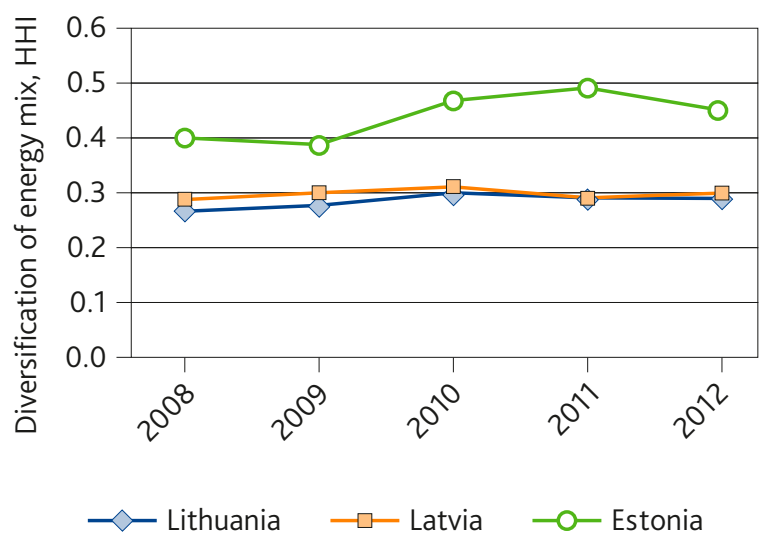

Figure 5. Diversification of energy mix in Baltic States Source: European Commission. 2016. Eurostat, Energy Statistics Database http://ec.europa.eu/eurostat/data/database

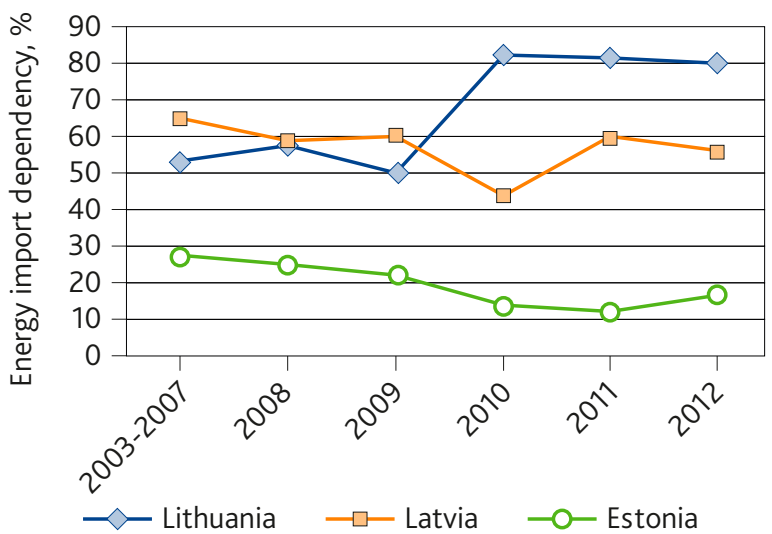

Figure 4. Energy import dependency in Baltic States Source: European Commission. 2016. Eurostat, Energy Statistics Database http://ec.europa.eu/eurostat/data/database

trends of energy mix diversification were favourable in Estonia in other analysed countries the situation remained stable during the investigated period.

It also becomes clear that Latvia distinguishes with very high share of renewables in final energy which is well above EU-28 level. In Estonia and Lithuania the share of renewables in final energy is also above EU28 level and has increased significantly since 2004 (by almost $70 \%$ ). The high share of renewables in Latvia is related with the natural conditions and high share of hydro in electricity generation. Comparing results achieved by new EU member states with target one can notice that Estonia achieved level above target set for 2020 in 2011 . The target for EU-28 is $20 \%$ of renewables in final energy consumption and in 2013 EU-28 reached almost $10 \%$.

It is necessary to stress that there is a close relationship between green growth indicators as increase in the share of renewables and energy efficiency improvements have direct impact on reduction of energy and carbon intensity of economy and all sectors as well as on decrease of energy import dependency,

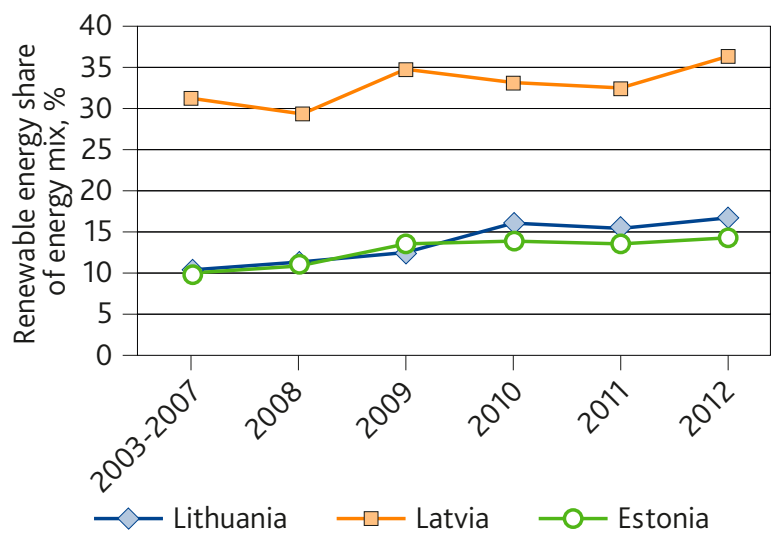

Figure 6. Renewable energy share of energy mix in Baltic States Source: European Commission. 2016. Eurostat, Energy Statistics Database http://ec.europa.eu/eurostat/data/database 
energy balance of trade and diversification of energy mix.

\section{Conclusions}

Overall, it becomes obvious that "green" growth is expected in implementation of Europe 2020 strategy and can provide harmonized development and cohesion of old and new EU member states. Europe 2020 is the EU's growth based on the growth of smart, sustainable and inclusive economy. Energy security is one of the most important issues to be addressed by member states in implementing Europe 2020 strategy.

Moreover, there is close relationship between energy dependency and security indicators as the increase in the share of renewables and energy efficiency improvements have direct impact on reduction of energy carbon intensity of economy and all sectors as well as on decrease of energy import dependency, energy balance of trade and diversification of energy mix.

When comparing Baltic States in terms of progress achieved in energy security, the most important indicators addressing these issues were selected, including energy import dependency, energy and carbon intensity as well as contribution of energy products to trade given its potential impact on the current account deficit.

It has to be noticed that Estonia distinguishes from other Baltic States with good results achieved in achieving several energy security indicators such as high share of renewables in final energy consumption and lowest rate of energy dependency however country has very high energy and carbon intensity of economy and it's particular branches though significant decrease in energy intensity and carbon intensity of energy can be noticed during investigated period.

In addition, Latvia also distinguishes with very high shares of renewables in electricity generation and in final energy consumption however it is more related with favourable climate conditions and well developed hydro power plants.

Furthermore, Lithuania distinguishes with the best indicators of energy and carbon intensity of economy as well as energy and carbon intensity of specific branches of economy, however country has the worst indicator of energy dependency including energy dependency indicators related to trade.

All in all, it appears that Lithuania needs more policies to increase energy efficiency and use of renewables and increase diversification of fuel mix. This will allow reducing energy dependency rate and current account vulnerability to energy price shocks as Lithuania has very high the contribution of trade in energy products to an external imbalance.

\section{References}

Balitskiy, S., Bilan, Y., Strielkowski, W. 2014. Energy security and economic growth in the European union. Journal of Security and Sustainability Issues 4,2, 125-132.

Balitskiy, S., Bilan, Y., Strielkowski, W., Streimikiene, D. 2016. Energy efficiency and natural gas consumption in the context of economic development in the European Union. Renewable \& Sustainable Energy Reviews 55, 156-168.

Białowąs, P. 2015. The models of business organization in the light of the privatization process on the example of Polish electricity sector. Journal of International Studies 7,3, 234-243. DOI: 10.14254/20718330.2015/8-3/19

Bilan, Y., 2013. Sustainable development of a company: building of new level relationship with the consumers of XXI century. Amfiteatru Economic 15, 687-701.

Cappelen, A., Castellacci, F., Fagerberg, J., Verspagen, B. 2003. The impact of EU regional support on growth and convergence in the European Union. Journal of Common Market Studies 41,4, 621644. DOI: 10.1111/1468-5965.00438

Ciegis, R., Pileckaite, R., Pusinaite, R., 2014. Impact of oil and natural gas prices on the economy and consumers in Lithuania. Transformations in Business \& Economics 13,1, 107-123.

Clowes, D., Choroś-Mrozowska, D. 2015. Aspects of global security - the measurement of power \& its projection. Results from twenty selected countries (2000-2013). Journal of International Studies 8,1, 5366. DOI: $10.14254 / 2071-8330.2015 / 8-1 / 5$

Csigéné Nagypál, N., Görög, G., Harazin, P., Péterné Baranyi, R. 2015. Future Generations and Sustainable Consumption. Economics \& Sociology 8,4, 207224. DOI: 10.14254/2071-789X.2015/8-4/15

Dresner, S., The Principles of Sustainability. 2nd edn. London: Earthscan. 2008, ISBN 9781844074969.

European Commission 2016. Eurostat, Energy Statistics Database. http://ec.europa.eu/eurostat/data/database

European Commission 2014. European Economy. Members States Energy Dependence: an IndicatorBased Assessment, 2014 Brusselss.

European Commission 2015. Country Report Latvia 2015. COM (2005) 85 final), 2015a. http://ec.europa. eu/europe2020/pdf/csr2015/cr2015_latvia_en.pdf

European Commission 2005. Country Report Lithuania 2015. COM (2005) 85 final), 2015b. http:// ec.europa.eu/europe2020/pdf/csr2015/cr2015_lithuania_en.pdf

European Commission 2015. Country Report Estonia 2015. COM (2005) 85 final), 2015c. http://ec.europa. eu/europe2020/pdf/csr2015/cr2015_estonia_en.pdf 
Hallegatte, S., Heal, G., Fay, M., Treguer, D. 2011. From Growth to Green Growth. The World Bank, Policy Research Working Paper. http://www-wds.worldbank.org/servlet/WDSContentServer/WDSP/IB /2011/12/07/oo0158349_20111207171314/Rendered/ PDF/WPS5872.pdf

Heal, G. 2013. Reflections-defining and measuring sustainability. Rev. Environ. Econ. Policy No. 6 (1), 147-163. Green Growth Knowledge Platform. Moving towards a Common Approach on Green Growth Indicators. A Green Growth Knowledge Platform Scoping Paper.

Jänicke, M. 2011. Ffu-Report 09-2011: "Green Growth": From a growing eco-industry to a sustainable economy. FFU-Report 09-2011, Forschungszentrum für Umweltpolitik, FU Berlin, 18 Seiten. www.gws-os. com/discussionpapers/gws-researchreport13-1.pdf

Kasperowicz, R. 2015. Economic growth and $\mathrm{CO}_{2}$ emissions: the ECM analysis", Journal of Inter- national Studies 8,3, 91-98. DOI: 10.14254/20718330.2015/8-3/7

Pazeraite, A., Krakauskas, M., Mikalauskiene, A., 2014. Spread of clean technologies in Lithuanian electricity sector. Transformations in Business \& Economics 13,1, 174-187

Reilly, J. 2012. Green Growth and the Efficient Use of Natural Resources. Energy Economics 34 (Suppl. 1), S85-S93.

Schmalensee, R. 2012. From "Green Growth" to sound policies: An overview. Energy Economics 34, 52-56.

Vasauskaite, J., Streimikiene, D., 2014. Review of energy efficiency policies in Lithuania. Transformations in Business \& Economics 13,3 C, 628-642.

Urbaniec, M. 2015. Towards Sustainable Development through Ecoinnovations: Drivers and Barriers in Poland. Economics \& Sociology 8,4, 179-190. DOI: 10.14254/2071-789X.2015/8-4/13. 